City University of New York (CUNY) CUNY Academic Works

\title{
Excavating a Future Vision Past: Mike Davis' City of Quartz
}

William Blick

Queensborough Community College

\section{How does access to this work benefit you? Let us know!}

More information about this work at: https://academicworks.cuny.edu/qb_pubs/79

Discover additional works at: https://academicworks.cuny.edu

This work is made publicly available by the City University of New York (CUNY).

Contact: AcademicWorks@cuny.edu 
City University of New York (CUNY) CUNY Academic Works

\section{Excavating a Future Vision Past: Mike Davis' City of Quartz}

William Blick

Queensborough Community College

\section{How does access to this work benefit you? Let us know!}

More information about this work at: https://academicworks.cuny.edu/qb_pubs/79

Discover additional works at: https://academicworks.cuny.edu

This work is made publicly available by the City University of New York (CUNY).

Contact: AcademicWorks@cuny.edu 


\section{Excavating a Future Vision Past: Mike Davis' City of Quartz}

When Mike Davis published City of Quartz in 1990, his work was widely praised by many and in some manner dismissed as liberalist hysteria by others. While his prophecies are not prophetic in the exact, and while his examination of what he perceives as a disharmonious relationship with ecology may come across as exaggerated radical-rousing, City of Quartz arguably stands the test of time. The reflections it contains on architectural design as reflection of socio-political tumult still strike chords today. This article sets out a survey and a re-examination of the text through hindsight, demonstrating how and to what extent the book was relevant or irrelevant at the time of its publication, and how it may be relevant or irrelevant today. Through the analysis of contemporary and subsequent critical responses, a review of reviews, this article seeks to illuminate how and why City of Quartz has had a profound impact on sociological and cultural studies, despite the polarization of ideologies evident in these responses to the work. The work itself is dynamically unique because of its arguments and its broad range of pop cultural and political references, as well as its profound exploration of what a nonfiction book can do by existing as both polemic and noir-ish composite of a city. The reevaluation of the impact of such a work is thus quite compelling.

This article follows the trajectory of City of Quartz's influence and places it in the context with other comparable writings in the field of architecture and space, and the relationship to sociology, including Marxism. It then follows a selection of reviews written at the time of the book's release and shortly thereafter to indicate its critical response and relevance. These reviews were chosen from a wide range of sources including popular, literary magazines as well as peerreviewed journal articles to ensure a broad perspective towards the work, which walks a fine line 
between academia and popular non-fiction. City of Quartz's enduring quality is that the issues raised in the book remain pertinent today. Topics like neoliberalism and the class and race chasms that make up Los Angeles, which were viewed through a critical lens in the original work in 1990, continue to make the book appealing today, even if there are some items that seem anachronistic.

Using the historical development of the city of Los Angeles in Central California, USA, Davis set out to demonstrate how space and spatial constructions both manufacture and reflect the societal anxieties of a particular time period, and what society's reaction is to these elements. He delves into popular culture, film, literature, historical events and movements to exemplify how Los Angeles reflects repressive attitudes towards equality, diversity and economic class. Simultaneously, the book can be viewed as a sort of "neo-noir nonfiction," with elements of mystery and intrigue. By reflecting on Los Angeles, a city like no other in the United States (or anywhere else for that matter), with distinct cultural and sociopolitical characteristics and geography, Davis is able to achieve a substantial feat of cultural analysis irrespective of whether the audience agrees or disagrees with the political views presented.

Davis' book was intended to reach mass audiences of readers who were liberal minded and educated. Davis has an articulate voice that resonates in a diverse range of circles, from other authors to anyone interested in U.S. history, or for use in higher education including architecture, sociology, urban studies, film history, popular culture, and noir-fiction courses. The book is not an academic exercise, though it can be (and clearly has been) used for academic purposes, and has had an effect upon various academic debates and disciplines. For example, in her 1992 review of City of Quartz, Sharon Zukin explains that spatiality, or general laws that are related to cultural and economic systems, have become a necessary focus in urban studies since the early 
80s, or as she states, "a critical linchpin in social structure." City of Quartz stems from the evolution of this movement.

Davis begins his work with a comprehensive history of converging ideals, schemes, and dreams that different groups had for this still underdeveloped Los Angeles reaching back to the fin de siècle. Groups of intelligentsia, bohemians, right wing Christians, white supremacists, and socialist communes all tried to make a go of it in the otherwise barren landscape. Through the book, he ultimately works his way up to what was then contemporary Los Angeles: there, City of Quartz was a resounding response to what appeared to be a militarization and restrictive element present not only in Los Angeles, but in an ever-increasing neoliberalism which fed a hegemonic system that seemed especially pronounced in the Bush administration (1989 to 1993), during which the book was published.

The socio-political pendulum has swung left and right since then, yet it may be one of the first non-fiction books whose politics are pronounced and border on esoteric, but still maintain a stylistic, engrossing read for the layperson through the use of what appear to be noir genre elements. I first encountered the text when I read this for a non-fiction genre writing class. It spoke to me because the ideas and concepts were abstract, yet these abstractions took the form of films and cultural ideas I could relate to. Ultimately, it was a fascinating read because of the fact that Davis was able to tap into the elements that modern civilization draws from to create a metropolis. City of Quartz addresses the evolution of a city, but saw Los Angeles as especially unusual because of its landscape, climate, and finally, its architecture and space. Davis makes direct comparisons to film noir such as The Postman Always Rings Twice, and dystopian visions such as Blade Runner. He also goes to great lengths to explain and debunk religious sects such as Scientology, and explains at length the influence of the Studio System. The little people of the 
studio system, whose lives were desperate and despairing, are the subject of another film and novel which Davis uses as a reference point to describe the window of neurosis of L.A. That film is John Schlesinger's Day of the Locust, adapted from Nathanel West's novel, whose prose describes the "spiritually starving" in the shadow of the major studios. Also, Davis mentions the sort of hobo-literature personified by writers like John Fante, and later Charles Bukowski, as well as the work of Chester Himes, a disenfranchised African-American crime fiction writer and social critic who evolved from the early days of L.A., and who depicted Los Angeles as a "racial hell."

From these and other disenfranchised elements in Los Angeles culture, Davis was able to create a sense of noir genre non-fiction from the city, and thus generate a mystique that piqued this reader's interest. In a recent critical essay by Christopher Wilson, the critic outlines the emergence of this new genre and the challenges is presents, explaining:

I will turn here to a twentieth-century group of practitioners of the Los Angeles variant of Noir nonfiction: the activist, architectural critic, and prizewinning historian of Los Angeles, Mike Davis... Davis, for instance, opens the final chapter of his much-disputed history, City of Quartz... with a quote from Didion; the penultimate chapter of City of Quartz is called "New Confessions" and is virtually a rewrite of Dunne's signature novel, True Confessions... I will turn more directly to nonfiction and reportage, demonstrating how Noir can challenge customary realist norms of voice, evidence, and the representation of power. ${ }^{\text {ii }}$

Davis eschews the usual conventions of nonfiction and through his style, he adds to the feeling of anomaly and the imbalance of power and wealth present within the city limits of Los Angeles, coming up with this new form of political expression, the noir nonfiction. Noir seems to be the 
primary technique and aesthetic lens through which Davis approaches the problems Los Angeles. He chooses popular movies, books, and history to build his case, many of them detective or hardboiled movies or books. He uses all the tropes of a mystery and dark underbelly beneath the long acres of orange groves.

In the early 1990s, there was considerable concern about the crime rate, particularly in the predominately African-American South Central of Los Angeles. John Singleton's Boyz in the Hood and the Hughes Brothers' Menace to Society are just two films to come out at this time, indicative of an awareness raised by rappers, activists, and the sheer volume of media coverage about the cyclical poverty and gang violence in Los Angeles. The area was a virtual warzone. Gang activity still exists there, but there are other regions of the country that have superseded concern about crime in Los Angeles: for example, the city of Chicago, often nicknamed "Chiraq." Understood in this context, the publication of City of Quartz coincided with the frightening implications of a fragmented society, socio-economic chasms. In a way, City of Quartz was prophetic about these ensuing issues. The issue of poverty and the economic gap between rich and poor still exists, manifesting itself also in visible architectural constructs of space. Yet the one thing that has changed since then is the leadership in the country, namely Trump. Trump's policies seemed to have exacerbated the poor race relations that City of Quartz identifies. Trump is the wildcard that Davis did not prophesy. While Davis' trend was towards dystopia, he read the future as one of class warfare, but not the ideological battle that exists today. Yet his vision is still relevant, as apathy grows about ghettos and cyclical poverty.

An interview with Mike Davis in Publishers Weekly Magazine in 1998 explains that Davis has something of a devout following in Southern California, and that City of Quartz was considered the authority on the history and sociology of Los Angeles. ${ }^{\text {iii }}$ Obviously, Davis makes 
no efforts to conceal his urgent affiliation with current socialist agendas. This alignment dominates the book, as he portrays a grim picture of this land of broken dreams that were also reflected in the films of the times and subsequently.

In 1992, Decker, writing for American Quarterly, puts forward a unique idea of the agenda of City of Quartz. He states, "the book makes extensive use of poststructuralist notions of the social construction and circulation of power," and goes onto explain that Davis describes a

"fragmented, paranoid spatiality which subjects individuals and groups to a seemingly disembodied circulation of disciplinary power. From downtown architecture that produces schizophrenia to Westside lawns that threaten trespassers with "Armed Response" signs, Southern Californians are obsessed with policing themselves and others. It is a terrain that affords no design for democracy but, rather, only dark models for democratic totalitarianism". iv

Whether Davis' work is on or of spatial paranoia, and whether it retains relevance today, remain open questions, but the allegedly racially-motivated homicides by police of people of color continue to resonate, as does class division in Los Angeles, which is still a wide open chasm.

Using a Marxist lens in Paris: Capital of Modernity, David Harvey demonstrates the prime shaping forces that led to the current socio-economic state of modern, capitalist Paris. $\mathrm{He}$ explains that Marx, like many other thinkers, was influenced by Balzac. He explains, quoting Balzac, that in all spaces of Paris "there is a mode of being which reveals what you are, what you do, where you come from, and what you are after." ${ }^{\text {" }}$ This is not unlike the argument that Davis leads with. Harvey's emphasis of the physical distances that separate classes are understood in more detail as a separation of social classes that exists through both spatial ecologies and vertical 
segregations. Paris has elite locations inhabited by men of science and genius; on the first floors of houses are the well-filled stomachs; on the ground floor are the shops, the legs and feet, since the busy trot of trade goes in and out of them. The spatial pattern anchors a moral order. ${ }^{\mathrm{vi}}$ These types of divisions can be seen presently in major U.S. Cities, but may be more pronounced in the large stretch that is California.

Another key thinker about urbanity and its problems is Andy Merrifield, whose revolutionary ideas about how capitalism shapes landscapes link back to Harvey. Andy Merrifield reminds the reader that:

"the English sociologist Ray Pahl published a collection of essays under a simple yet disarming title, 'Whose City?' Pahl asks the following questions: What were the mechanisms whereby capitalists—increasingly finance capitalists- commandeered the city in the way they did? Through what means did they make it their city? How did planning authorities, land-use allocations, and various state agencies perpetuate or undermine this 'system'? Furthermore, in his questioning of the thriving capitalist system, he argues the city 'is what society lets it be'."’vii

Merrifield questions how and why modern cities become the way they are, namely because of corporate mechanism commandeering cities by increasing capital.

Davis' book is incredibility important to many people and strikingly relevant, while others view it as Marxist propaganda and paranoia, falling into pseudo genre fiction in a postmodern stew of fragmented soothsaying. As a result of the polarizing effect of City of Quartz, the book has been contested by scholars and popular readers alike. This polarization is a reflection of the aforementioned identity crises that Los Angeles has and continues to face due to its wide 
range of cultural influences, including Hollywood culture and industry, and the various early settlers of the city with their conflicting ideologies.

As Tim Zindel of Library Journal states though, Davis' observations may be truer than they are false as he eschews the mindset that ignores racial and police-state-like tactics to control neighborhoods. In Zindel's brief blurb at the time of publication, the staff author names the book, a "necessary" work. ${ }^{\text {viii }}$ Indeed, Davis uses architectural and civil planning creations to explain how they reflect efforts to preserve middle class structures, while making life more difficult for the indigent and underprivileged. Bus benches, landscaping, and elaborate social structures exist to widen the gap between the haves and have-nots. Celebrity architect Frank Gehry takes efforts to create a siege-like arrangement of the Hollywood Library (1985), one of the last bastions of democracy, and makes it reminiscent of Foreign Legion fort. William Whyte, a social critic known for his "Project for Public Spaces," explained that a successful architectural theme is based on how many places are made comfortable for pedestrians to sit. Yet, apparently it is strangely adhered to by many city architects and planners. It would seem that the architects and planners would strike a balance between utility and aestheticism, yet the emphasis on comfort for pedestrians seems somewhat disconcerting.

Whyte's book Rediscovering the Center (1988), which came out two years prior to Davis' book, also evaluates space and observes its usage in urban areas. He calls to mind several prominent elements that occupy space in cities, and that seem indigenous to many great cities: food and drink, particularly the occupation of space by food vendors, which were defended by Whyte as providing a catering need that other larger establishments cannot fill. He also observes plazas and building entrances in particular their use of artwork and sculpture, which are defining 
characteristics of empty space, as well as the occupation of parks, which Whyte notices are never really overcrowded. ${ }^{\text {ix }}$

If one were to place Davis in the context of Whyte, we can see the similarities of their argument about the reflection of social values found in spatiality. While Whyte's primary concern is more or less observational, Davis follows up where Whyte left off, with staunch political position regarding urban spatiality. There appears to be considerable clashes between increasing quality of life versus and increase in capital gain. Writers such as Whyte, Harvey, Merrifield, and Davis all question the modern need for expansion and the problematic handling of spatiality.

Modarres, writing for the Journal of Urban Affairs in 1996, calls City of Quartz a “disjointed tableaux" and criticizes Davis for not addressing immigration, assimilation, and ethnic community development within the context of Los Angeles'social and economic environment. Modarres also explains that Davis' book is one that describes “a junk yard of broken dreams destroyed by capitalism." Davis, finally, is lauded for his achievement in demystifying academic writing and subjects and for making them readable and engrossing. ${ }^{\mathrm{x}}$

While Modarres represents many who applaud Davis' attention to the "junk yard," others accuse him of being gloomy and overlooking urban improvement: One of the fiercest critical reviews came of Todd Purdum in 1999 in the New York Times. Purdum accused Davis of mixing up facts to fit his own agenda: "he has so twisted the facts as to make honest debate impossible. The latest critique of Mr. Davis, for example, in the weekly New Times L.A., leaves little doubt that his new book's portrait of suburban Pomona as a deserted husk is at best outdated, ignoring a decade of revival." ${ }^{\mathrm{xi}}$ 
Linda Mcdowell wrote a glowing article on City of Quartz for the Times Higher Education Supplement five years after its publication. Her passion for the work after several years speaks volumes of its impact on readers. She explains that Davis does not paint a picture of glitz and glam, but of "a city with a strong centre, both literal and metaphorical, based on privilege and the exclusion of the majority of the population from the utopian dreams of the affluent." Mcdowell latches onto Davis' idea that LA, especially downtown, is "a literal bunker, a fortress built on Bunker Hill to protect the interests of the rich and keep out the poor, the homeless, the people of every race and color who live in the surrounding neighborhoods." ${ }^{\text {xii }}$

From a perspective taken a decade later, Rooksby, writing for Class and Capital in 2006, states that "Mike Davis's City of Quartz is now firmly established as something of a modern classic in the field of urban sociology, and is widely regarded as being the defining social history of Los Angeles. Davis's account of Los Angeles frequently conjures up a sense of ominous foreboding — a dark vision of a city on the verge of some apocalyptic explosion." "xiii As Davis himself explains, "Social Anxiety, as traditional urban sociology likes to remind us, is just maladjustment to change. But who has adjusted to the scale of change in Southern California over the past 15 years?"xiv Davis contends that Los Angeles is a dynamic city in constant transitional, geographic, and architectural flux. As a result, there is a schizophrenic identity that the city is afflicted with. This identity crisis leads to many social ills.

In surveying the reviews both contemporary and more recent, there appears to be more praise than criticism of City of Quartz. Whether you agree with it or not, it still remains an important neo-classic in social science, urban studies, and architecture. A reread of Davis' book begs the question: Have things gotten worse or better? This question is difficult to gauge. Davis tries, though not very hard, to be a passive and objective viewer of the gestalt that makes up Los 
Angeles. Yet the reader is left with a sense of dread and an inevitable call to action. As much as Davis might have tried otherwise, the book is essentially a call for social justice. It is impossible for anyone to write a book like this and not politicize its meaning. Davis suggests that architecture is both the symptom and harbinger of social degeneration to come. Capitalism is an enemy of equality and Los Angeles seems to have the magical ability to turn anything into a commodity.

Yet the commodification of just about everything in Los Angeles leads to a disposable society, one that has many searching through the refuse to find value. Davis attempts to puncture the land of golden opportunity and transform it into a gilded, superficial phantasmagoric carnival of grotesquery all caused by capitalization and a fear of social degeneration.

City of Quartz is a unique work that has left an indelible print in the disciplines of architecture, sociology, and urban studies. It is an affective read and one that inspires thoughtful introspection about urbanity and the post-modern condition. Somewhat sensational, and somewhat groundbreaking, City of Quartz remains essential reading for those interested in the aforementioned fields of study

\section{References}

Davis, Mike. 1990. City of Quartz: Excavating the Future in Los Angeles. London: Verso, or New York: Alfred Knopf, Inc.

Decker, J. (1992). "Postmodernity, or, the Worlding of America." American Quarterly, 44(1), 146-154. doi:10.2307/2713187

Harvey, David. 2003. Paris, Capital of Modernity. Routledge.

Mantell, Suzanne. "Mike Davis: Flirting with Disaster.” Publishers Weekly 245, no. 35 (August 31, 1998): 42.

Mcdowell, Linda. "Speaking Volumes; Books". The Times Higher Education Supplement. March 24, 1995. 
Merrifield, Andy. New Urban Question, Pluto Press, 2014.

Modarres, Ali. 1996. "Book Reviews.” Journal of Urban Affairs 18 (1): 77.

Pahl, R. E. 1976. Whose City?: And Further Essays on Urban Society. London: Penguin Books.

Purdum, Todd . "Best-Selling Author's Gloomy Future for Los Angeles Meets Resistance". The New York Times. January 27, 1999, Wednesday, Late Edition - Final.

Rooksby, Edward. 2008. "City of Quartz: Excavating the Future in Los Angeles." Capital \& Class 32 (94): 151-54.

Whyte, William H. City: Rediscovering the Center. Philadelphia: University of Pennsylvania Press, 2009.

Wilson, Christopher P. "When noir meets nonfiction." Twentieth Century Literature, vol. 61, no. 4, 2015, p. 484.

Zindel, Tim. 1991. "City of Quartz: Excavating the Future in Los Angeles (Book)." Library Journal. 116 (1): 125.

Zukin, Sharon. "The Postmodern Invasion.” International Journal of Urban \& Regional Research 16, no. 3 (September 1992): 489.

\section{Filmography}

Hughes, Albert and Allen (Directors) Menace II Society. New Line Cinema

Tay Garnet (Director). 1946. The Post Man Always Rings Twice. MGM.

Ridley Scott (Director). 1982. Blade Runner. Warner Media.

John Schlesinger (Director). 1975. Day of the Locust. Paramount Pictures.

John Singelton (Director). 1991. Boyz in the Hood. Columbia Pictures.

Endnotes

i Zukin, Sharon. “The Postmodern Invasion.” International Journal of Urban \& Regional Research 16, no. 3 (September 1992): 489

ii Wilson, Christopher P. "When noir meets nonfiction." Twentieth Century Literature, vol. 61, no. 4,2015 , p. 484.

iii Mantell, Suzanne. "Mike Davis: Flirting with Disaster." Publishers Weekly 245, no. 35 (August 31, 1998): 42.

iv Decker, J. (1992). "Postmodernity, or, the Worlding of America." American Quarterly, 44(1), 146-154. doi: $10.2307 / 2713187$ 
v Harvey, David. Paris, Capital of Modernity, Routledge, 2003.

${ }^{\text {vi }}$ Ibid

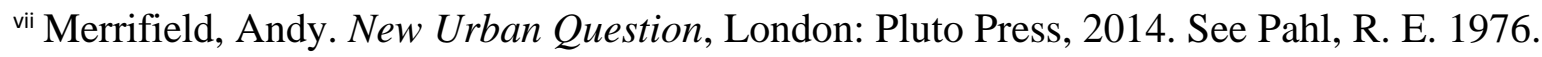
Whose City?: And Further Essays on Urban Society. London: Penguin Books.

viii Zindel, Tim. 1991. “City of Quartz: Excavating the Future in Los Angeles (Book).” Library Journal 116 (1): 125.

ix Whyte, William H. City: Rediscovering the Center. Philadelphia: University of Pennsylvania Press, 2009.

x Modarres, Ali. 1996. “Book Reviews.” Journal of Urban Affairs 18 (1): 77.

${ }^{x i}$ Purdum, Todd. 1999. "Best-Selling Author's Gloomy Future for Los Angeles Meets Resistance". The New York Times. Wednesday January 27, Late Edition - Final.

xii Mcdowell, Linda. 1995. "Speaking Volumes; Books". The Times Higher Education Supplement. March 24.

xiii Rooksby, Edward. 2008. "City of Quartz: Excavating the Future in Los Angeles." Capital \& Class 32 (94): 151-54. doi:10.1177/030981680809400115.

xivDavis, Mike. 1990. City of Quartz: Excavating the Future in Los Angeles. London: Verso.6. 